\title{
HUBUNGAN FAKTOR SOSIOEKONOMI DENGAN SALURAN PEMBUANGAN AIR LIMBAH (SPAL) DI DESA JAMBERAMA KECAMATAN SELAJAMBE
}

\author{
Nissa Noor Annashr \\ Program Studi Kesehatan Masyarakat STIKes Kuningan \\ annashr.nissa46@gmail.com
}

\begin{abstract}
Abstrak
Kuningan merupakan daerah endemis filariasis dengan jumlah kasus sebanyak 48 kasus pada tahun 2016. Penelitian Mardiana (2011) menunjukkan bahwa saluran pembuangan air limbah (SPAL) memiliki hubungan signifikan dengan kejadian filariasis. Desa Jamberama merupakan desa yang memiliki persentase KK paling rendah di Kecamatan Selajambe terkait kondisi SPAL yang memenuhi syarat yaitu hanya 20,29\% dari total KK yang diperiksa. Tujuan penelitian adalah menganalisis hubungan variabel sosioekonomi (tingkat pendidikan dan pekerjaan), dengan kondisi SPAL di Desa Jamberama, Kecamatan Selajambe. Penelitian ini dilakukan pada Bulan Agustus hingga September tahun 2016. Penelitian ini menggunakan rancangan cross sectional. Populasi dalam penelitian ini adalah seluruh KK di Desa Jamberama, Kecamatan Selajambe, Kabupaten Kuningan. Teknik pengambilan sampel menggunakan total sampling sehingga jumlah sampel penelitian sebanyak $469 \mathrm{KK}$ karena semua anggota populasi dijadikan sampel. Instrumen penelitian yang digunakan dalam penelitian ini berupa kuesioner. Analisis data terdiri dari analisis univariat dan analisis bivariat, menggunakan uji chi square. Hasil penelitian menunjukkan terdapat hubungan yang signifikan antara variabel tingkat pendidikan dan pekerjaan dengan kondisi SPAL $(\mathrm{p}=0,004$ dan $\mathrm{p}=0,001)$. Berdasarkan hasil penelitian, diharapkan pemerintah dapat meningkatkan upaya promotif untuk meningkatkan pengetahuan masyarakat terkait SPAL dan dampaknya terhadap kesehatan, serta berupaya untuk membangun program pemberdayaan pembuatan SPAL sederhana berbasis masyarakat.
\end{abstract}

Kata kunci : pekerjaan, SPAL,tingkat pendidikan

\section{Pendahuluan}

Filariasis merupakan salah satu penyakit menular yang masih menjadi masalah kesehatan dan erat sekali kaitannya dengan kondisi lingkungan. Filariasis adalah penyakit akibat infeksi cacing nematoda yang mengalami perubahan siklus hidup (stadium seksual) dan menjadi dewasa di dalam kelenjar getah bening manusia sebagai pejamu definitif, serta ditularkan oleh berbagai spesies nyamuk (Chandra, 2009 dan Muslim, 2009).
Penyakit ini merupakan penyebab utama kecacatan, stigma sosial, hambatan psikosial, penurunan produktivitas kerja individu, keluarga dan masyarakat sehingga menimbulkan kerugian ekonomi yang besar (Muslim, 2009). Kuningan merupakan daerah endemis filariasis dengan jumlah kasus 41 kasus pada tahun 2015 serta pada tahun 2016 terdapat 48 kasus.

Penelitian Mardiana (2011) menunjukkan bahwa saluran pembuangan air limbah memiliki hubungan signifikan 
dengan kejadian filariasis, dimana dalam rumah tangga yang saluran pembuangan air limbah (SPAL) terbuka memiliki risiko lebih besar untuk terkena filariasis dibandingkan saluran yang tertutup. Penelitian Santoso (2014) juga menunjukkan bahwa terdapat hubungan signifikan antara kondisi saluran pembuangan air limbah (terbuka dan tertutup) dengan kejadian filariasis. Hingga saat ini, pencegahan filariasis dengan vaksinasi belum dapat dilakukan sehingga pemberantasan vektor menjadi salah satu strategi yang penting bagi pencegahannya (Slamet, 2004). Prinsip utama untuk pencegahan filariasis dan pengendaliannya adalah menghindarkan diri dari gigitan vektor infektif dan kontak dengan vektor nyamuk, juga dengan memperbaiki keadaan lingkungan. Salah satunya adalah dengan cara menutup, menimbun, mengeringkan atau mengalirkan genangan air sebagai tempat perindukan nyamuk (Widiasih, 2012). Hal ini berarti harus ada pengelolaan air limbah yang baik dalam skala rumah tangga untuk menghindari adanya tempat perkembangan vektor.

Air limbah merupakan salah satu faktor sanitasi yang menjadi perhatian pemerintah Indonesia. Masalah sanitasi, pemukiman kumuh dan air minum merupakan aspek dari Universal Access yang ingin dicapai oleh Pemerintah Indonesia dan mencapai target 100-0-100. Artinya akses terhadap sanitasi mencapai target $100 \%$, pemukiman kumuh $0 \%$ dan target untuk akses air minum mencapai $100 \%$. Yang termasuk target pemerintah dalam aspek sanitasi disini adalah meningkatkan akses penduduk terhadap sanitasi layak (air limbah domestik, sampah dan drainase lingkungan) menjadi $100 \%$ pada tingkat kebutuhan dasar. Dalam RPJPN 2005-2025 (Rencana Pembangunan Jangka Panjang Nasional 2005-2025), disebutkan bahwa "pembangunan dan penyediaan air minum dan sanitasi diarahkan untuk mewujudkan terpenuhinya kebutuhan dasar masyarakat."
Berdasarkan data Bappenas RI, persentase cakupan akses sanitasi di Indonesia pada tahun 2014 mencapai $61,06 \%$, sedangkan target MDGs sebesar $62,41 \%$. Sementara itu, data menunjukkan di Provinsi Jawa Barat tahun 2014, persentase akses layak sanitasi sebesar $61,7 \%$, akses sanitasi dasar mencapai 3,9\% sehingga terdapat $34,4 \%$ penduduk di Jawa Barat yang tidak ada akses terhadap sanitasi.

Kecamatan Selajambe merupakan salah satu kecamatan di Kabupaten Kuningan yang memiliki masalah terkait sanitasi lingkungan. Data sekunder yang diperoleh dari Puskesmas Selajambe tahun 2015 menunjukkan bahwa dari total KK yang terdapat di Kecamatan Selajambe, baru $35,58 \%$ KK yang memiliki SPAL dengan kondisi yang memenuhi syarat. Sementara itu, Desa Jamberama merupakan salah satu desa di Kecamatan Selajambe yang memiliki persentase KK paling rendah terkait kondisi SPAL yang memenuhi syarat yaitu hanya $20,29 \%$ dari total KK yang dilakukan pemeriksaan.

Tujuan penelitian adalah menganalisis hubungan antara variabel sosioekonomi yaitu tingkat pendidikan dan pekerjaan, dengan kondisi SPAL di Desa Jamberama, Kecamatan Selajambe.

\section{Metode Penelitian}

Penelitian ini dilakukan pada Bulan Agustus hingga September tahun 2016 di Desa Jamberama, Kecamatan Selajambe, Kabupaten Kuningan. Penelitian ini termasuk jenis penelitian observasional analitik dengan menggunakan rancangan cross sectional. Populasi dalam penelitian ini adalah seluruh Kepala Keluarga (KK) di Desa Jamberama, Kecamatan Selajambe, Kabupaten Kuningan. Teknik pengambilan sampel menggunakan total sampling sehingga jumlah sampel penelitian sebanyak 469 KK karena semua anggota populasi dijadikan sampel penelitian. 
Instrumen penelitian yang 1digunakan adalah kuesioner dimana dilakukan wawancara kepada sampel penelitian untuk mengetahui variabel independen berupa tingkat pendidikan dan jenis pekerjaan serta variabel dependen berupa kondisi saluran pembuangan air limbah. Analisis data terdiri dari analisis univariat dan analisis bivariat, menggunakan uji chi square.

\section{Hasil Penelitian}

Tabel 1. Gambaran Tingkat Pendidikan Masyarakat Desa Jamberama, Kecamatan Selajambe

\begin{tabular}{ccc}
\hline Tingkat pendidikan & Frekuensi & Persentase \\
\hline $\begin{array}{c}\text { Rendah (tidak tamat SD, tamat SD } \\
\text { dan tamat SMP) }\end{array}$ & 423 & 90,19 \\
$\begin{array}{c}\text { Tinggi (tamat SMA dan Perguruan } \\
\text { Tinggi) }\end{array}$ & 46 & 9,81 \\
\hline Total & 469 & $100 \%$ \\
\hline
\end{tabular}

Berdasarkan tabel 1. diketahui bahwa sebagian besar masyarakat di Desa Jamberama memiliki tingkat pendidikan rendah yaitu sebanyak 423 orang (90,19\%). Variabel tingkat pendidikan tersebut dikategorikan menjadi 2 yaitu pendidikan rendah dan tinggi berdasarkan
PP No 47 Tahun 2008 tentang Wajib Belajar. Kategori pendidikan rendah jika masyarakat tidak pernah sekolah, tidak tamat SD, tamat SD dan SMP, serta kategori pendidikan tinggi jika masyarakat tamat SMA dan Perguruan Tinggi.

Tabel 2. Gambaran Pekerjaan Masyarakat Desa Jamberama, Kecamatan Selajambe

\begin{tabular}{ccc}
\hline Pekerjaan & Frekuensi & Persentase \\
\hline $\begin{array}{c}\text { Pekerjaan dengan penghasilan tidak } \\
\text { tetap }\end{array}$ & 415 & $88,49 \%$ \\
$\begin{array}{c}\text { Pekerjaan dengan penghasilan tidak } \\
\text { tetap }\end{array}$ & 54 & $11,51 \%$ \\
\hline Total & 469 & $100 \%$ \\
\hline
\end{tabular}

Berdasarkan tabel 2. diketahui bahwa sebagian besar masyarakat Desa Jamberama memiliki pekerjaan dengan penghasilan tidak tetap yaitu sebanyak 415 orang $(88,49 \%)$. Variabel pekerjaan tersebut dikategorikan menjadi 2 yaitu pekerjaan dengan penghasilan tetap dan pekerjaan dengan penghasilan tidak tetap. Yang dimaksud dengan pekerjaan dengan penghasilan tetap adalah jenis pekerjaan dimana setiap bulannya masyarakat menerima gaji atau pendapatan yang tetap dan dapat diprediksi dari pekerjaan tersebut, seperti PNS, pegawai swasta dan perangkat desa. Sedangkan yang masuk kategori pekerjaan dengan penghasilan tidak tetap adalah masyarakat yang bekerja sebagai petani, buruh tani, buruh bangunan dimana mereka memperoleh penghasilan yang tidak tetap setiap bulannya.

Tabel 3. Gambaran Kondisi Saluran Pembuangan Air Limbah (SPAL) di Desa Jamberama, Kecamatan Selajambe 


\begin{tabular}{ccc}
\hline Variabel Kondisi SPAL & Frekuensi & Persentase \\
\hline SPAL tidak memenuhi syarat & 461 & $98,3 \%$ \\
SPAL memenuhi syarat & 8 & $1,7 \%$ \\
\hline Total & 469 & $100 \%$ \\
\hline
\end{tabular}

Tabel 3. menunjukkan bahwa hanya 8 orang $\mathrm{KK}(1,7 \%)$ yang memiliki SPAL dengan kondisi memenuhi syarat (tertutup). Masyarakat dengan kategori SPAL tidak memenui syarat berarti masyarakat tersebut sama sekali tidak memiliki SPAL sehingga langsung mengalirkan air limbah rumah tangganya ke got di dekat rumahnya serta masyarakat yang memiliki SPAL tapi kondisinya terbuka

Hasil Analisis Bivariat

Tabel 4. Hubungan Tingkat Pendidikan dan Pekerjaan dengan Kondisi SPAL di Desa Jamberama, Kecamatan Selajambe, Kabupaten Kuningan.

\begin{tabular}{|c|c|c|c|c|c|}
\hline \multirow{2}{*}{ Variabel } & \multicolumn{2}{|c|}{ SPAL } & \multirow{2}{*}{ Total } & \multirow{2}{*}{$p$ value } & \multirow{2}{*}{$\begin{array}{c}\text { OR } \\
(95 \% \mathrm{CI})\end{array}$} \\
\hline & Terbuka & Tertutup & & & \\
\hline Tingkat Pendidikan & $419(99,1 \%)$ & $4(0,9 \%)$ & $423(100 \%)$ & 0,004 & 9,976 \\
\hline $\begin{array}{cc}- & \text { Rendah } \\
- & \text { Tinggi }\end{array}$ & $42(91,3 \%)$ & $4(8,7 \%)$ & $46(100 \%)$ & & $(2,407-41,345)$ \\
\hline Jenis pekerjaan & $412(99,3 \%)$ & $3(0,7 \%)$ & $415(100 \%)$ & 0,001 & 14,014 \\
\hline $\begin{array}{c}\text { - Tidak tetap } \\
\quad \text { Tetap }\end{array}$ & $49(90,7 \%)$ & $5(9,3 \%)$ & $54(100 \%)$ & & $(3,249-60,443)$ \\
\hline
\end{tabular}

Berdasarkan analisis bivariat menggunakan uji chi square antara variabel tingkat pendidikan dan kondisi SPAL didapatkan nilai $\mathrm{p}$ sebesar 0,004 (p $<0,05)$, sehingga terdapat hubungan yang signifikan antara variabel tingkat pendidikan dengan kondisi SPAL. Begitu juga untuk analisis hubungan variabel pekerjaan dan kondisi SPAL menunjukkan nilai $\mathrm{p}<0,05$ yaitu $\mathrm{p}$ sebesar 0,001 sehingga variabel pekerjaan memiliki hubungan yang signifikan dengan SPAL

\section{Pembahasan}

\section{Hubungan Tingkat Pendidikan dan SPAL}

Hasil penelitian ini menunjukkan variabel tingkat pendidikan memiliki hubungan yang signifikan dengan kondisi SPAL $(\mathrm{p}<0,05)$. Menurut Mubarak
(2007:30), banyak faktor yang dapat mempengaruhi pengetahuan seseorang, salah satunya adalah faktor pendidikan. Pendidikan itu sendiri dapat diklasifikasikan menjadi pendidikan formal dan nonformal. Pendidikan formal adalah pendidikan melalui jalur persekolahan dimana ada jenjang pendidikan dasar, menengah, dan tinggi. Pendidikan informal diperoleh melalui kegiatan-kegiatan pelatihan atau kursus. Sementara itu, pendidikan nonformal berlangsung di lingkungan keluarga dan masyarakat. Dari hasil penelitian juga diketahui bahwa sebagian besar masyarakat di Desa Jamberama memiliki tingkat pendidikan formal yang rendah (tamat SD dan tamat SMP) dengan persentase sebesar $90,19 \%$. Hal ini tentu akan mempengaruhi pengetahuan dari masyarakat di Desa Jamberama itu sendiri. 
Sebagaimana penelitian yang dilakukan oleh Suherman (2015) di Kelurahan Lekobalo, menunjukkan bahwa sebagian besar penduduk di sana termasuk kategori pendidikan rendah yaitu sebanyak 55 orang $(66,3 \%)$. Hasil penelitian mengenai variabel tingkat pengetahuan tentang ketersediaan saluran pembuangan air limbah menunjukkan bahwa paling banyak responden memiliki pengetahuan kurang yaitu sebanyak 67 orang $(80,7 \%)$. Hal tersebut menunjukkan pengetahuan dapat dipengaruhi dari tingkat pendidikan seseorang. Sementara itu dari hasil uji chi square didapatkan nilai $\mathrm{p}=0,006$ ( $\mathrm{p}$ value $<0,05)$ sehingga terdapat hubungan yang signifikan antara tingkat pengetahuan masyarakat dengan ketersediaan saluran pembuangan air limbah. Penelitian yang dilakukan oleh Nurhabibah (2015) juga menunjukkan hasil yang sama dimana terdapat hubungan yang bermakna antara variabel tingkat pengetahuan dengan kondisi SPAL rumah tangga.

Tingkat pendidikan merupakan salah satu faktor internal yang dapat mempengaruhi seseorang termasuk juga perilaku seseorang akan pola hidup, terutama dalam memotivasi untuk sikap berperan serta dalam pembangunan. Pada umumnya semakin tinggi pendidikan seseorang maka akan membuat orang tersebut cenderung semakin mudah menerima informasi (Wawan dan Dewi, 2011 : 16). Dengan demikian, rendahnya pendidikan seseorang dapat mencerminkan bahwa pengetahuan yang dimilikinya pun kurang. Saat sebagain besar masyarakat di Desa Jamberama memiliki pendidikan yang rendah maka pengetahuan yang dimiliki terkait kesehatan khususnya pengaruh SPAL terhadap kesehatan juga kurang.

Pengetahuan yang kurang tersebut juga dapat mempengaruhi sikap serta pada akhirnya mempengaruhi perilaku seseorang. Sebagaimana Kholid (2012 : 23) mengemukakan bahwa alur perubahan perilaku seseorang dipengaruhi oleh adanya faktor pengetahuan, kemudian pengetahuan mempengaruhi sikap dan terakhir sikap akan mempengaruhi perilaku seseorang. Menurut Teori Green (1980) dalam Notoatmodjo (2014 : 75-76), perilaku seseorang dipengaruhi oleh 3 faktor utama, yang dirangkum dalam akronim PRECEDE : Predisposing, Enabling, dan Reinforcing Causes in Educational Diagnosis and Evaluation. Perubahan perilaku model PRECEDE menguraikan bahwa perilaku itu sendiri ditentukan 3 faktor, yakni 1) Faktor predisposisi (predisposing factors), yang terwujud dalam pengetahuan, sikap, kepercayaan, keyakinan, nilai-nilai, dan sebagainya, 2) Faktor pemungkin (enabling factors), yang terwujud dalam lingkungan fisik dan sarana kesehatan, dan 3) Faktor pendorong atau penguat (reinforcing factors), yang terwujud dalam sikap dan perilaku petugas kesehatan atau petugas lain.

Dengan pendidikan yang rendah, maka masyarakat Desa Jamberama tidak memiliki pengetahuan yang cukup mengenai SPAL, manfaat SPAL dan bagaimana dampaknya terhadap kesehatan. Selain itu, pendidikan yang rendah juga mempengaruhi kesadaran masyarakat yang kurang terkait pembangunan SPAL di rumah mereka masing-masing.

\section{Hubungan Pekerjaan dan SPAL}

Hasil penelitian menunjukkan bahwa variabel pekerjaan memiliki hubungan yang signifikan dengan kondisi SPAL. Hasil ini tidak sejalan dengan penelitian yang dilakukan oleh Suwastika (2010) dimana dalam penelitiannya tidak ditemukan adanya hubungan antara tingkat penghasilan dengan pemanfaatan sarana sewerage system pada masyarakat pinggiran kali di Kelurahan Dangin Puri Kecamatan Denpasar Timur.

Faktor-faktor yang mempengaruhi status kesehatan pada masyarakat memang sangat kompleks. Gunnar Myrdall dalam Sulastomo (2007 : 16) mengesankan bahwa adanya korelasi antara kesehatan 
dan ekonomi sebagaimana yang disebutkan, "people are sick, because they are poor.They become poorer because they are sick. And they become sicker because they are poorer". Untuk mencapai derajat kesehatan yang baik, faktor-faktor yang mepengaruhi derajat kesehatan itu harus mmperoleh perhatian secara simultan, salah satunya adalah faktor ekonomi.

$$
\text { Dengan demikian dapat }
$$

disimpulkan bahwa saat seseorang memiliki pekerjaan dengan penghasilan tidak tetap per bulannya dimana penghasilannya pun masih tergolong menengah ke bawah, maka orang tersebut akan cenderung sulit untuk dapat mengakses fasilitas kesehatan dan daya belinya terhadap pemenuhan kebutuhan kesehatan juga rendah. Hal ini berarti dengan penghasilan yang tidak tetap maka masyarakat Desa Jamberama rasa belum mampu untuk membuat SPAL di rumahnya karena proses pembuatan SPAL itu sendiri membutuhkan biaya yang cukup besar. Padahal di satu sisi, pembuatan SPAL yang memenuhi syarat akan memberikan manfaat yang besar bagi pencegahan penyakit berbasis lingkungan terutama yang ditularkan oleh vektor penyakit, apalagi Kuningan merupakan salah satu kabupaten di Jawa Barat yang menjadi daerah endemis penyakit tular vektor seperti filariasis dan DBD.

Sebagaimana kita ketahui bersama bahwa pencemaran air dapat terjadi karena adanya air limbah yang dibuang tanpa pengolahan ke dalam suatu badan air. Air limbah yang tidak dikelola dengan baik selain dapat merusak lingkungan, juga dapat menimbulkan gangguan kesehatan pada manusia.Air limbah yang menggenang tersebut dapat menjadi tempat perkembangbiakan (breeding place) vektor penyakit, seperti nyamuk.

Menurut Khambali (2017 : 98), penyediaan sarana pembuangan air limbah yang baik merupakan salah satu upaya yang dapat dilakukan untuk mengendalikan vektor penyakit. Hal tersebut juga merupakan salah satu bentuk upaya pengelolaan lingkungan untuk menghilangkan genangan air.

\section{Kesimpulan dan Saran}

\section{Kesimpulan}

Variabel tingkat pendidikan dan pekerjaan memiliki hubungan yang signifikan dengan kondisi SPAL di Desa Jamberama, Kecamatan Selajambe, Kabupaten Kuningan.

\section{Saran}

Berdasarkan hasil penelitian, maka diharapkan pemerintah dapat meningkatkan upaya promotif untuk meningkatkan pengetahuan masyarakat terkait SPAL dan dampaknya terhadap kesehatan serta berupaya untuk membangun program pemberdayaan pembuatan SPAL sederhana berbasis masyarakat.

\section{Ucapan Terimakasih}

Ketua Yayasan Pendidikan Bhakti Husada Kuningan, Ketua STIKes Kuningan, Ketua Lembaga Penelitian STIKes Kuningan, IAKMI Kab. Kuningan, Dinas Kesehatan Kab. Kuningan, Puskesmas Selajambe dan masyarakat Desa Jamberama.

\section{Referensi}

Bappenas RI. Agenda Nasional Pembangunan Air Minum dan Sanitasi 2015-2019. Tidak dipublikasikan

Chandra, B. (2009). Ilmu Kedokteran Pencegahan dan Komunitas. Jakarta : Penerbit Buku Kedokteran EGC

Khambali, I. (2017). Manajemen Penanggulangan Bencana. Yogyakarta : Penerbit ANDI

Kholid, A. (2012). Promosi Kesehatan dengan Pendekatan Teori Perilaku, Media, dan Aplikasinya. Depok : Raja Grafindo Persada. 
Mardiana, Lestari, E. W., dan Perwitasari, D. (2011). Faktor-Faktor yang Mempengaruhi Kejadian Filariasis di Indonesia (Data Riskesdas 2007). Jurnal Ekologi Kesehatan. Vol. 10 (2) : $83-92$

Mubarak, Wahit Iqbal, Chayatin, Nurul, Rozikin, Khoirul dan Supradi. (2007). Promosi Kesehatan Sebuah Pengantar Proses Belajar Mangajar dalam Pendidikan. Yogyakarta: Graha Ilmu.

Muslim, M. (2009). Parasitologi untuk Keperawatan. Jakarta : Penerbit Buku Kedokteran EGC

Nurhabibah. (2015). Hubungan Perilaku Masyarakat dengan Kondisi Saluran Pembuangan Air Limbah Rumah Tangga di Wilayah Kerja Puskesmas Tapus Kecamatan Padang Gelugur Kabupaten Pasaman Tahun 2015 http://scholar.unand.ac.id/2077/ (diakses 11 Mei 2018)

Slamet, J. S. (2004). Kesehatan Lingkungan. Yogyakarta : Gadjah Mada University Press

Santoso. (2014). Hubungan Faktor Lingkungan Fisik dengan Kejadian Filariasis di Indonesia. Jurnal Ekologi Kesehatan Vol. 13 No 3, September $2014: 210-218$

Suherman, H. R., Saraswati, D. dan Bialangi, S. 2015. Hubungan Tingkat Pengetahuan dan Sikap Masyarakat dengan Ketersediaan Saluran Pembuangan Air Limbah di Kelurahan Lekobalo.

http://kim.ung.ac.id/index.php/KIMFI KK/article/view/11340 (diakses 11 Mei 2018)

Sulastomo. (2007). Manajemen Kesehatan. Jakarta : PT. Gramedia Pustaka Utama

Suwastika, I., D., G. dan Dwipayanti, N., M., U. (2010). Faktor-Faktor Yang Mempengaruhi Ketersediaan Septictank Dan Pemanfaatan Sarana Sewerage System Pada Masyarakat Pinggiran Kali Di Kelurahan Dangin Puri Kecamatan Denpasar Timur. Kongres Nasional Ikatan Ahli
Ciptaan disebarluaskan di bawah Lisensi Creative Commons AtribusiNonKomersial-BerbagiSerupa 4.

Kesehatan Masyarakat Indonesia, Bandung, 3-5 Agustus 2010

Wawan dan Dewi. (2011). Teori \& Pengukuran Pengetahuan, Sikap dan Perilaku Manusia. Yogyakarta : Nuha Medika.

Widiasih, D. A. dan Budiharta, S. (2012). Epidemiologi Zoonosis di Indonesia. Yogyakarta : Gadjah Mada University Press 